\title{
Dynamics, chemical properties and bioavailability of DOC in an early successional catchment
}

\author{
U. Risse-Buhl ${ }^{1}$, F. Hagedorn ${ }^{2}$, A. Dümig ${ }^{3}$, M. O. Gessner ${ }^{4,5,6,7}$, W. Schaaf ${ }^{8}$, S. Nii-Annang ${ }^{8}$, L. Gerull ${ }^{1}$, and M. Mutz ${ }^{1}$ \\ ${ }^{1}$ Department of Freshwater Conservation, Brandenburg University of Technology Cottbus, Seestraße 45, \\ 15526 Bad Saarow, Germany \\ ${ }^{2}$ Department of Soil Sciences, Swiss Federal Institute of Forest, Snow and Landscape Research, Züricherstrasse 111,8903 \\ Birmensdorf, Switzerland \\ ${ }^{3}$ Lehrstuhl für Bodenkunde, Department für Ökologie und Ökosystemmanagement, Wissenschaftszentrum Weihenstephan für \\ Ernährung, Landnutzung und Umwelt, Technische Universität München, 85350 Freising-Weihenstephan, Germany \\ ${ }^{4}$ Leibniz Institute of Freshwater Ecology and Inland Fisheries (IGB), Alte Fischerhütte 2, 16775 Stechlin, Germany \\ ${ }^{5}$ Department of Ecology, Berlin Institute of Technology (TU Berlin), Ernst-Reuter-Platz 1, 10587 Berlin, Germany \\ ${ }^{6}$ Department of Aquatic Ecology, Eawag: Swiss Federal Institute of Aquatic Science and Technology, Überlandstrasse 133, \\ 8600 Dübendorf, Switzerland \\ ${ }^{7}$ Institute of Integrative Biology (IBZ), ETH Zurich, 8092 Zurich, Switzerland \\ ${ }^{8}$ Department of Soil Protection and Recultivation, Brandenburg University of Technology Cottbus, \\ Konrad-Wachsmann-Allee 6, 03046 Cottbus, Germany \\ Correspondence to: U. Risse-Buhl (ute.risse-buhl@tu-cottbus.de)
}

Received: 30 December 2012 - Published in Biogeosciences Discuss.: 24 January 2013

Revised: 31 May 2013 - Accepted: 3 June 2013 - Published: 15 July 2013

\begin{abstract}
The dynamics of dissolved organic carbon (DOC) have been intensively studied in mature ecosystems, but little is known about DOC dynamics and the significance of DOC as a substrate for microbial activity in earlysuccessional catchments. We determined the concentration, chemical composition, source, radiocarbon age, and bioavailability of DOC along the hydrological flow path from soil solution to a downstream pond in a recently constructed catchment (Chicken Creek Catchment, Germany). Soil solution, upwelling ground water, stream water, subsurface water in an alluvial fan, and pond water all had high DOC concentrations (averages: $6.0-11.6 \mathrm{mg} \mathrm{DOC} \mathrm{L}^{-1}$ ), despite small carbon stocks in both vegetation and soil of the catchment. Solid-state CPMAS ${ }^{13} \mathrm{C}$ NMR of DOC in upwelling ground water revealed a higher proportion of aromatic compounds (32\%) and a lower proportion of carbohydrates (33\%) than in pond water (18\% and $45 \%$, respectively). The average ${ }^{14} \mathrm{C}$ age of DOC in upwelling ground water was 2600 to $2900 \mathrm{yr}$, while organic matter of the Quaternary substrate of the catchment had a ${ }^{14} \mathrm{C}$ age of 3000 to $16000 \mathrm{yr}$. Both the ${ }^{14} \mathrm{C}$ age data and ${ }^{13} \mathrm{C}$ NMR spectra suggest that DOC
\end{abstract}

partly derived from organic matter of the Quaternary substrate (about 40 to $90 \%$ of the C in the DOC), indicating that both recent and old C of the DOC can support microbial activity during early ecosystem succession. However, in a 70 day incubation experiment, only about $11 \%$ of the total DOC was found to be bioavailable. This proportion was irrespective of the water type. Origin of the microbial communities within the catchment (enriched from soil, stream sediment or pond water) also had only a marginal effect on overall DOC utilization.

\section{Introduction}

Dissolved organic carbon (DOC) plays an important role in carbon cycling across the pedosphere and hydrosphere (Battin et al., 2008), sustaining an important fraction of microbial biomass production and metabolic activities in both terrestrial and aquatic ecosystems (e.g., Kalbitz et al., 2000; Tranvik et al., 2009). The potential of DOC to sustain microbial activities, i.e., DOC bioavailability, is controlled by 
the supply rate and composition of DOC (e.g., Findlay et al., 2003; Kalbitz et al., 2003; Ågren et al., 2008), in addition to a range of environmental factors and the nature of the microbial communities, which vary across the landscape from upland soils to streams and lakes (Judd et al., 2006). In mature ecosystems, young and labile DOC derived from primary producers and allochthonous terrestrial sources are primary drivers of microbial activity in the upper soil horizon, streams and lakes (Wetzel, 1992; Kalbitz et al., 2003; Tranvik et al., 2009). Between 10 and $44 \%$ of the DOC is readily available for microbial metabolism in soils (Kalbitz et al., 2000), and in streams and rivers even up to $70 \%$ (Wiegner et al., 2006).

Microbial degradation of labile DOC fractions and conversion of a portion into more refractory DOC components (Tranvik, 1993; Berggren et al., 2009) has been found to reduce the bioavailability of DOC during downstream transport from upland soils to receiving waters (Sobczak and Findlay, 2002; Romaní et al., 2006). However, supplies from local sources can increase the average DOC bioavailability along this hydrological flow path. Selective sorption at mineral surfaces further contributes to changes in DOC chemical properties and bioavailability (McDowell, 1985; Fiebig and Marxsen, 1992; McKnight et al., 1992). For example, highmolecular weight DOC such as humic and fulvic acids shows high affinity to metal oxides and clays (e.g., McKnight et al., 1992; Meier et al., 1999; Specht et al., 2000; Kaiser et al., 2002). Thus, fluxes of DOC in a catchment are controlled by a combination of biological, chemical and physical processes (Battin et al., 2008), generating considerable potential for DOC to be modified during transport from upland soils to streams and lakes. Microbial communities may vary along this hydrological flow path and might be adapted to the composition of the local DOC pools.

Unlike mature ecosystems, recently formed ecosystems such as deglaciated soils or sand dunes are characterized by sparse vegetation and low soil organic matter content (Bardgett and Walker, 2004; Bernasconi et al., 2011; Schaaf et al., 2011). These characteristics affect the sources, quantity and chemical properties of DOC in such catchments. For example, the ${ }^{14} \mathrm{C}$ age of stream water DOC in glacierfed streams in the recently formed landscape of partly deglaciated coastal catchments along the Gulf of Alaska and in the Austrian Alps was estimated at several millennia (Hood et al., 2009; Singer et al., 2012). Nevertheless, the DOC originating from the melting glaciers was found to be readily bioavailable for microbial communities, possibly due to a high protein and low aromatic carbon content (Hood et al., 2009; Singer et al., 2012).

The recent construction of an experimental catchment on Quaternary substrate in an opencast mining area (Gerwin et al., 2009) provides an opportunity to study the behaviour of DOC along hydrological flow paths during the early phases of ecosystem succession, independent of any legacy effects occurring in deglaciated landscapes. Less than $2.2 \mathrm{mg}$ soil organic matter $\mathrm{g}^{-1}$ of the Quaternary substrate (Gerwin et al., 2009) and low microbial biomass and respiration in soils and sediments (Gerull et al., 2011; Nii-Annang et al., 2009) reflect the early stage of ecosystem succession in this catchment. This contrasts with remarkably high DOC concentrations (5.1 to $18.3 \mathrm{mg} \mathrm{DOC} \mathrm{L}^{-1}$ ) measured in soil solution, ground water, stream water, and pond water (Elmer et al., 2013; Gerull et al., 2011), suggesting that DOC may be an important driver of microbial activity in the catchment.

The present study conducted along a hydrological flow path from upland soils to a downstream pond in the earlysuccessional experimental catchment aimed at (i) identifying the sources of DOC, (ii) determining changes in DOC quantity and chemical properties, (iii) ascertaining whether DOC drives microbial activity, and (iv) assessing whether microbial communities are adapted to utilizing DOC of varying quality. We hypothesized that DOC in the catchment is primarily old organic matter inherited from the Quaternary substrate, that this old DOC serves as the primary substrate for microbial activity, and that chemical properties and bioavailability of the DOC shift along the hydrological flow path from upland soils to the downstream pond.

\section{Materials and methods}

\subsection{Study site}

The study was carried out in the Chicken Creek Catchment constructed in 2004 and 2005 in an opencast pit-mining area (Welzow-Süd) of Lower Lusatia, Germany $\left(51^{\circ} 37^{\prime} \mathrm{N}\right.$, $14^{\circ} 18^{\prime} \mathrm{E}$; Fig. 1). A detailed description of the site is given in Gerwin et al. (2009). The catchment covers a total area of 6 ha $(400 \mathrm{~m} \times 150 \mathrm{~m})$. The south-facing slope has a mean gradient of $3.5 \%$. The substrate used to construct the catchment was sand and loamy sand deposited as a terminal moraine during the Saale glacial period. The substrate was removed from the upper $20 \mathrm{~m}$ of the glacial deposits, resulting in a dominance of $\mathrm{C}$-horizon material with low organic carbon content (Gerwin et al., 2011).

A clay layer underlying the sand at a depth of 1 to 3.5 meters facilitated rapid development of a local aquifer. Within $2 \mathrm{yr}$ after construction of the catchment, surface runoff had carved a network of rills, gullies and three main stream channels from the initially smooth catchment surface (Fig. 1). Upwelling ground water delivered permanent flow over short stretches of the stream channels ( 20 to $43 \mathrm{~m}$ length), in which mean discharge ranged from 0.02 to $0.4 \mathrm{~L} \mathrm{~s}^{-1}$ (Gerull et al., 2011). Downstream, the water seeped into the subsurface of an alluvial fan that had formed from substrate eroded during peak flows of up to $35 \mathrm{~L} \mathrm{~s}^{-1}$. Subsurface water in the alluvial fan was a mixture of ground water and stream water. All surface water and ground water draining from the catchment discharged into a small pond just downstream of the alluvial fan. The mean water residence time was estimated 
at $<1$ day in the streams (calculated based on daily mean discharge) and at $<300$ days in the pond. Annual precipitation in the catchment averaged $706 \mathrm{~mm}$ between 2008 and 2010 (Elmer et al., 2013; Fischer et al., 2010), higher than the long-term mean of $559 \mathrm{~mm}$ recorded at a nearby meteorological station of the German Weather Service (station Cottbus) between 1971 and 2000.

During the first years after catchment construction, the soil surface was covered by soil crusts that increased soil water holding capacity and surface runoff (Elmer et al., 2013). By 2010, patches of forbs and grasses had been established on the initially bare substrate. Common reed, Phragmites australis, spread on the alluvial fan, along parts of the pond margin, and in the downstream portions of the stream channels. Submerged macrophytes colonized the pond, particularly Potamogeton, Myriophyllum and Chara species. Annual mean chlorophyll $a$ concentration in the pond water ranged from 5 to $7 \mu \mathrm{g} \mathrm{L}^{-1}$ between 2008 and 2009, whereas up to $25 \mu \mathrm{g} \mathrm{L}{ }^{-1}$ were recorded in 2010 (Elmer et al., 2011).

\subsection{Sample collection}

Dynamics of DOC concentrations in soil solution, ground water, stream water, and pond water were monitored between September and November 2010. Sampling sites are shown in Fig. 1. Soil solution was collected over successive two-week periods in soil pits at 30 and $80 \mathrm{~cm}$ depth using porous borosilicate glass suction plates $(10 \mathrm{~cm}$ diameter) with a permanent pressure of $-10 \mathrm{kPa}$. A weir and an $\mathrm{H}$-flume equipped with ultrasonic sensors and a V2A tipping counter (2 FT-H-flume for flow rates up to $315 \mathrm{~L} \mathrm{~s}^{-1}$; UGT GmbH, Müncheberg, Germany) were installed to monitor the flow of ground water and stream water, respectively, in one of the three main stream channels in the catchment. Continuous records were also taken at the pond outlet using a V-notch weir combined with a tipping counter. Both weirs and the H-flume were equipped with automated water samplers (ISCO 6712 or ISCO 3700; Teledyne Isco, Inc., Lincoln, NE, USA) to monitor concentrations of DOC and other chemical parameters. Water samples were taken daily, pooled in the laboratory to obtain two-week composite samples and stored at $4{ }^{\circ} \mathrm{C}$.

Bioavailability and chemical properties of DOC were determined in April 2010 during a period of constant stream flow. Three spatially independent samples of each of four water types were taken to account for spatial heterogeneity in the catchment and all other sources of variability (Fig. 1). Soil solution was collected at $30 \mathrm{~cm}$ depth in three soil pits over a period of 3.5 weeks (as described above). Upwelling ground water was collected in each of the three main stream channels at the sites where ground water surfaced. For this purpose, perforated tubes covered by a $220 \mu \mathrm{m}$ mesh screen were inserted into the stream sediment to a depth of $5 \mathrm{~cm}$. The inflowing water was collected with a syringe. Subsurface water in the alluvial fan (hereafter called subsurface wa-

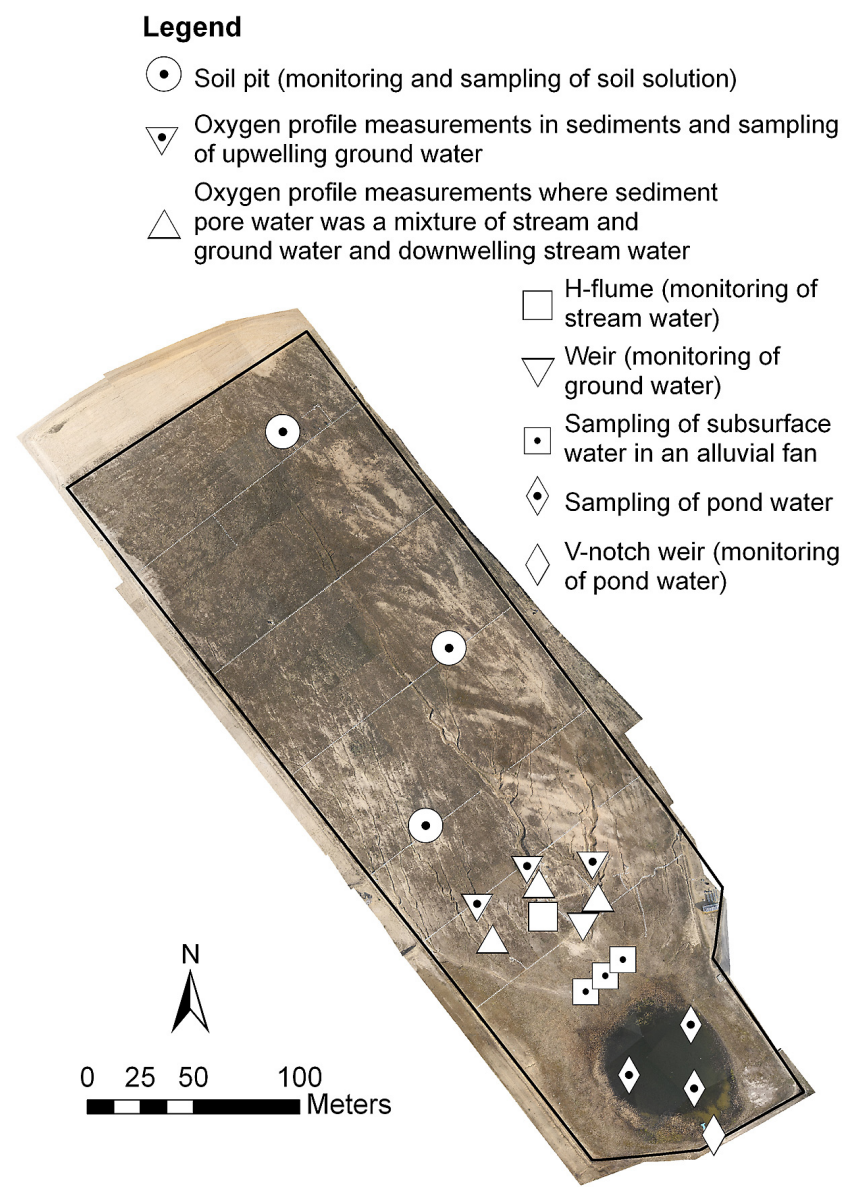

Fig. 1. Aerial photograph of the Chicken Creek Catchment taken in April 2010 with various kinds of sampling sites indicated by different symbols. Solid black lines denote the catchment borders and gray lines are pathways to access the sampling sites of the otherwise undisturbed catchment. Density, depth and width of rills and gullies increase from northwest to southeast of the catchment, leading to the formation of three main streams. Dotted circle - soil pit (monitoring and sampling of soil solution), dotted downward pointing triangle - oxygen profile measurements in sediments and sampling of upwelling ground water, open upward pointing triangle - oxygen profile measurements where sediment pore water was a mixture of ground water and downwelling stream water, open square - $\mathrm{H}$ flume (monitoring of stream water), open downward pointing triangle - weir (monitoring of ground water), dotted square - sampling of subsurface water in an alluvial fan, dotted rhombus - sampling of pond water, open rhombus - V-notch weir (monitoring pond water).

ter) was sampled in three previously installed standpipes by slowly pumping water from 60 to $70 \mathrm{~cm}$ depth to the surface. All tubes and wells for sampling upwelling ground water and subsurface water were emptied three times before taking samples. In the pond, three mixed water samples were taken with a Ruttner water sampler at $0.5,1.0$ and $1.5 \mathrm{~m}$ depth. All water samples were filtered through pre-combusted GF/F filters and $0.2 \mu \mathrm{m}$ cellulose-acetate membrane filters (prewashed three times with ultrapure water and autoclaved) 
prior to analyses or experimental incubations. Temperature, oxygen concentration, $\mathrm{pH}$ and conductivity were measured at each site.

Oxygen depth profiles were measured in the upper $20 \mathrm{~cm}$ of the stream sediments using an oxygen microsensor ( $0.9 \mathrm{~mm}$ diameter; Microx TX 3, PreSense Precision Sensing $\mathrm{GmbH}$, Regensburg, Germany; Gerull et al., 2011). Profiles were taken in the three main stream channels at three sites each where sediment pore water was either upwelling ground water, a mixture of stream and ground water, or downwelling stream water (Fig. 1).

\subsection{Experimental set-up to assess DOC bioavailability}

Three distinct microbial communities sampled from soil, stream sediment from the upwelling section, and pond water were used as inocula to assess DOC bioavailability in a 70 day incubation experiment. To prepare the inocula, soil and sediment cores ( $3 \mathrm{~cm}$ diameter) were taken to a depth of $5 \mathrm{~cm}$. The upper $1 \mathrm{~cm}$ was discarded to exclude phototrophs. Three cores were taken at each of the two sites and pooled. In the laboratory, $40 \mathrm{~g}$ wet mass of the soil and sediment cores were suspended in $250 \mathrm{~mL}$ of Volvic mineral water. The suspensions were vigorously shaken before diluting $10 \mathrm{~mL}$ aliquots 25 fold. Volvic mineral water has a relatively low DOC concentration of $0.6 \mathrm{mg} \mathrm{L}^{-1}$ and has been successfully used as a culture medium for microbial organisms (Le DûDelepierre et al., 1996). Volumes of $250 \mathrm{~mL}$ of diluted soil and sediment suspensions as well as of the mixed pond water sample were subsequently incubated in Erlenmeyer flasks (acid washed and autoclaved) in the dark at $20 \pm 1{ }^{\circ} \mathrm{C}$ with gentle shaking (orbital shaker at $100 \mathrm{rpm}$, amplitude of $1 \mathrm{~cm}$ ). After 14 days, the resulting suspensions were passed through a $10 \mu \mathrm{m}$ mesh screen to remove any metazoans. Bacterial abundance in the soil inoculum was $1.2 \times 10^{6}$ cells mL $^{-1}$, in the stream-sediment inoculum $0.3 \times 10^{6}$ cells mL $^{-1}$, and in the pond-water inoculum $3.4 \times 10^{6}$ cells $\mathrm{mL}^{-1}$ (see below for analytical procedures).

A total of 33 microcosms ( $1 \mathrm{~L}$ glass flasks) were filled with $700 \mathrm{~mL}$ of filtered water (see above) collected in the field (triplicates of each water and inoculum type) or deionized water as a control (one replicate per inoculum type), 5 glass slides $(35 \times 17 \mathrm{~mm})$ to provide surface area for biofilm development, and a magnetic stirrer. All glassware and other materials were acid-washed and autoclaved. Upwelling ground water, subsurface water, and pond water were inoculated with $1 \mathrm{~mL}$ each of the three enriched microbial communities. Soil solution was inoculated exclusively with the enriched soil microbial community, because the available water volume was too small for additional treatments. This resulted in a total of 10 treatments. To prevent nutrient limitation during the experiment, microcosms received a buffered mineral salt solution containing $\mathrm{NaNO}_{3}$ and $\mathrm{Na}_{2} \mathrm{HPO}_{4}$ at final concentration of $16.7 \mathrm{mg} \mathrm{N} \mathrm{L}^{-1}$ and $2.1 \mathrm{mg} \mathrm{PL}^{-1}$, respectively. The average total dissolved nitrogen concentration in fil- tered (pre-washed $0.45 \mu \mathrm{m}$ cellulose acetate filters; Sartorius, Göttingen, Germany) water samples was $21.0 \pm 1.1 \mathrm{mg} \mathrm{L}^{-1}$, determined with a TOC/TN analyzer (TOC-VCPH TNM-1, Shimadzu, Tokyo, Japan) as described below. Addition of the nutrient solution increased conductivity by $20-30 \%$ above the initial value. Microcosms were incubated in a climate chamber at $20 \pm 1{ }^{\circ} \mathrm{C}$ in the dark for 70 days. Every day, microcosms were placed on a magnetic stirrer for $5 \mathrm{~min}$ to carefully mix the water column and to ensure oxygen saturation during the experiment.

\subsection{Analyses of bacterial abundance, respiration, and DOC}

Samples of suspended bacteria were taken from the inocula, at days 0,7 and 70 and fixed with formaldehyde (final concentration of $3.7 \%$ ). Bacteria from 70 day old biofilms were scraped off the glass slides with a scalpel, suspended in $25 \mathrm{~mL}$ autoclaved, particle-free water, and preserved with formaldehyde as above. Aliquots of 0.5 to $2 \mathrm{~mL}$ were concentrated on black polycarbonate membranes ( $0.2 \mu \mathrm{m}$ pore size; Sartorius, Göttingen, Germany), stained with DAPI (4' 6-diamidino-2-phenylindol, final concentration of $1 \mu \mathrm{g} \mathrm{mL}^{-1}$ ) as described in Nixdorf et al. (2003), and counted by epifluorescence microscopy.

Microbial respiration and DOC concentrations were determined in the four filtered water types, after 1 (microbial respiration only), 7, 14, 42 and 70 days of incubation. Microbial respiration of suspended and biofilm communities was determined with oxygen optodes (PreSens Precision Sensing $\mathrm{GmbH}$, Regensburg, Germany) by recording the oxygen decline in $50 \mathrm{~mL}$ glass flasks (Schlief and Mutz, 2011). Glass slides $\left(11.9 \mathrm{~cm}^{2}\right)$ were submerged in $47 \mathrm{~mL}$ of the corresponding water. The flasks were closed, ensuring that they were air-bubble free, and incubated for 14 to $21 \mathrm{~h}$ at $19^{\circ} \mathrm{C}$. Oxygen declines in sterile-filtered $(0.2 \mu \mathrm{m}$ cellulose acetate membrane; Sartorius, Göttingen, Germany) controls of each water type were used to correct the measured respiration rates (by 8 to $46 \%$ ). Respiration rates are presented as oxygen consumption of the suspended and biofilm communities per respiration chamber per hour (i.e., $\mathrm{mg} \mathrm{O}_{2}$ per $47 \mathrm{~mL}$ of water and $11.9 \mathrm{~cm}^{2}$ of biofilm area per hour).

DOC concentrations were determined in filtered (pre-washed $0.45 \mu \mathrm{m}$ cellulose acetate filters; Sartorius, Göttingen, Germany) water samples with a TOC/TN analyzer (TOC-VCPH TNM-1, Shimadzu, Tokyo, Japan). DOC added to the microcosms with the inoculum and the nutrient solution was estimated based on the difference in concentrations directly before and after adding the suspensions to the control microcosms. DOC data from day 0 are approximations of the calculated difference and the DOC concentration of the different filter-sterilized water types.

Absorbance spectra, carbohydrate concentrations, and $\delta^{13} \mathrm{C}$ values of DOC were determined in the four filtered water types $(0.45 \mu \mathrm{m})$ after 7 and 70 days of incubation. DOC 
absorbance $(A)$ between 235 and $375 \mathrm{~nm}$ was measured spectrophotometrically (Perkin Elmer, Waltham, MA, USA) in a quartz cuvette at room temperature, and was converted to an absorption coefficient, $a\left(\mathrm{~cm}^{-1}\right)$, according to

$a=2.303 \cdot A / S$,

where $S$ is the path length of the cuvette $(1 \mathrm{~cm})$. Dissolved iron at the concentrations found in all water types of the Chicken Creek Catchment $\left(<0.1 \mathrm{mg} \mathrm{L}^{-1}\right)$ does not interfere with the analysis (Weishaar et al., 2003). Specific UV absorption at $254 \mathrm{~nm}\left(\mathrm{SUVA}_{254}\right)$ calculated as $a_{254}$ divided by the DOC concentration was used as a proxy of DOC aromaticity (Weishaar et al., 2003), and the ratio of $a_{250} / a_{365}$ served as an indicator of the average size difference of DOC molecules (de Haan and de Boer, 1987).

Total carbohydrates, including mono-, oligo- and polysaccharides, as well as their methyl ethers, were analyzed by the phenol-sulfuric acid method with absorbance measured at $485 \mathrm{~nm}$ (Dubois et al., 1956). Data are reported as mg glucose equivalents $\mathrm{L}^{-1}$. Low-molecular-weight organic acids such as formiate, malate, tartrate, oxalate and citrate were measured by ion chromatography (ICS-3000, Dionex, Sunnyvale, CA, USA) equipped with an IONPAC ${ }^{\circledR}$ AS19 column and an IONPAC ${ }^{\circledR}$ AG11-HC pre-column.

Isotope-ratio mass spectrometry (IRMS; DELTA V Plus Advantage coupled with a Finnigan LC IsoLink interface, Thermo Scientific, Schwerte, Germany) of acidified samples $(\mathrm{pH}<2)$ was used to determine ${ }^{13} \mathrm{C} /{ }^{12} \mathrm{C}$ ratios of the DOC. The relative abundance of $\delta^{13} \mathrm{C}(\%)$ was calculated based on the relation:

$\delta^{13} \mathrm{C}=\left(Z_{\mathrm{sa}} / Z_{\mathrm{st}}-1\right) \cdot 10^{3}$,

where $Z_{\mathrm{sa}}$ is the ${ }^{13} \mathrm{C} /{ }^{12} \mathrm{C}$ ratio of the sample and $Z_{\text {st }}$ is the ${ }^{13} \mathrm{C} /{ }^{12} \mathrm{C}$ ratio of the international Pee Dee Belemnite (PDB) standard.

DOC of acidified $(\mathrm{pH}<2)$ and freeze-dried upwelling ground water and pond water samples (pooled replicates) were analyzed by solid-state ${ }^{13} \mathrm{C}$ nuclear magnetic resonance spectroscopy $\left({ }^{13} \mathrm{C}\right.$ NMR; DSX 200 NMR spectrometer, Bruker, Karlsruhe, Germany) using the crosspolarization magic angle spinning (CPMAS) technique (Schaefer and Stejskal, 1976; Peersen et al., 1993). The available sample volumes of soil solution and subsurface water were insufficient for this analysis. The chemical shifts of ${ }^{13} \mathrm{C}$ are expressed relative to tetramethylsilane $(=0 \mathrm{ppm})$. The NMR spectra were partitioned into four major chemical-shift regions whose areas were integrated to quantify the relative abundance of four functional groups (Knicker and Lüdemann, 1995): 0 to $45 \mathrm{ppm}=$ alkyl C, 45 to $110 \mathrm{ppm}=\mathrm{O}-/ \mathrm{N}$-alkyl C, 110 to $160 \mathrm{ppm}=$ aromatic $\mathrm{C}$, 160 to $220 \mathrm{ppm}=$ carboxyl $\mathrm{C}$.

Radiocarbon age of the DOC in upwelling ground water and the Quaternary substrate was measured from acidified $(\mathrm{pH}<2)$, freeze-dried samples at the Accelerator Mass Spectrometry facility operated by the Paul Scherrer Institute (PSI) and ETH Zurich, Switzerland. Results were corrected for blank values and isotopic fractionation (Stuiver and Polach, 1977). All ${ }^{14} \mathrm{C}$ contents are reported as $\Delta^{14} \mathrm{C}(\%)$, i.e., relative to the absolute radiocarbon content of the atmosphere in 1950 (Trumbore, 2000). Conventional radiocarbon ages were calculated following Stuiver and Pollach (1977) and calibrated using the OxCal program (Ramsey, 2001). These data are presented as years before present (years BP). The relative contribution of old and recent $\mathrm{C}$ was estimated using a binary mixing model:

$\Delta^{14} \mathrm{C}_{\text {DOC }}=f_{\text {subst }} \cdot \Delta^{14} \mathrm{C}_{\text {subst }}+\left(1-f_{\text {subst }}\right) \cdot \Delta^{14} \mathrm{C}_{\mathrm{atm}}$,

where $f_{\text {subst }}$ is the fraction of the Quaternary substrate and $\left(1-f_{\text {subst }}\right)$ the fraction of atmospheric $\mathrm{CO}_{2}$ in 2009 (with a $\Delta{ }^{14} \mathrm{C}$ value of $46.2 \%$ ), representing recently established vegetation.

\subsection{DOC fluxes}

A rough DOC budget for the pond was established by first estimating the water budget of the pond followed by multiplication of the fluxes by the DOC concentrations measured in time-integrated samples. The water budget of the pond was calculated on a daily basis for the years 2008 to 2010 as

$\mathrm{d} V_{\text {pond }} / \mathrm{d} t=Q_{\text {sgs }}+P_{\text {pond }}-E T_{\text {pond }}-Q_{\text {pond }}$,

where $\mathrm{d} V_{\text {pond }} / \mathrm{d} t$ is the water-volume change of the pond obtained by monitoring the water level, $Q_{\text {sgs }}$ is the total inflow into the pond by surface water, ground water and subsurface water, $P_{\text {pond }}$ is the precipitation on the pond surface, $\mathrm{ET}_{\text {pond }}$ is the estimated evapotranspiration from the pond surface, and $Q_{\text {pond }}$ is the measured outflow from the pond. Inflow via surface water, ground water and subsurface water could not be quantified separately. Therefore, $Q_{\text {sgs }}$ was used to calculate DOC inputs into the pond. To this end, the mean DOC concentrations determined in samples collected daily at the $\mathrm{H}$-flume and weir and subsequently pooled over two-week periods were multiplied by the water inflow $\left(Q_{\text {sgs }}\right)$ over the respective sampling periods. Likewise, DOC concentrations of the bulk precipitation $\left(P_{\text {pond }}\right)$ and the pond outflow $\left(Q_{\text {pond }}\right)$ were multiplied by the precipitation $\left(P_{\text {pond }}\right)$ and pond outflow $\left(Q_{\text {pond }}\right)$ cumulated over the respective sampling periods. Finally, DOC removal in the pond was calculated as the difference between total input and export as

$$
\begin{aligned}
\mathrm{dDOC} / \mathrm{d} t & =Q_{\mathrm{sgs}} \cdot \mathrm{DOC}_{\mathrm{sgs}}+P_{\text {pond }} \cdot \mathrm{DOC}_{\text {precip }} \\
& -Q_{\text {pond }} \cdot \mathrm{DOC}_{\mathrm{pond}} .
\end{aligned}
$$

\subsection{Statistical analyses}

To determine differences in DOC concentration among water types in three successive years (2008 to 2010), mean DOC concentrations were calculated from data collected between February and May each year. Differences were assessed by 
means of a permutation-based one-factorial analysis of variance (permANOVA). Permutation stopped when the estimated standard error of the estimated $p$ was less than $0.001 *$ $p$, which resulted in 5000 permutations (Anderson, 2001). In case of significant differences among water types, Tukey's post hoc test was used for pairwise comparisons.

The fractions of bioavailable and recalcitrant DOC were calculated by fitting DOC concentrations sampled at days 0 , 7, 14, 42 and 70 to an exponential decay model:

$\mathrm{DOC}_{\mathrm{t}}=\mathrm{DOC}_{\mathrm{r}}+\left(1-\mathrm{DOC}_{\mathrm{r}}\right) \cdot e^{\left(-k_{\mathrm{b}} \cdot t\right)}$,

where $\mathrm{DOC}_{\mathrm{t}}$ is the total DOC pool $(100 \%), \mathrm{DOC}_{\mathrm{r}}$ the recalcitrant DOC pool $(\%), 1-\mathrm{DOC}_{\mathrm{r}}$ the bioavailable DOC pool $(\%), k_{\mathrm{b}}$ the decay rate coefficient for the bioavailable DOC $\left(\right.$ day $\left.^{-1}\right)$, and $t$ is time (day). Turnover of the bioavailable DOC was estimated as $1 / k_{\mathrm{b}}$ (day). Before the analysis, mean DOC concentrations of each treatment were normalized by dividing them by the mean DOC concentration at day 0 of the corresponding treatment. Data of all water types and microbial communities were pooled.

PermANOVA of data collected in April 2010 was used to test for differences in DOC concentrations and chemical properties among the four water types. In addition, permANOVA was used to test for effects of water type, elapsed time, and the microbial community used for inoculation. The response variables in these analyses were microbial respiration and DOC concentration. Differences in DOC chemical properties between two time points during the incubation were determined by means of a permutation-based $t$ test (perm $t$ test). Pearson's correlation coefficient was used to examine relationships between variables.

\section{Results}

\subsection{Environmental parameters in April 2010}

Total bulk precipitation in April 2010 was $20.8 \mathrm{~mm}$. The catchment and pond were covered by snow and ice until late March 2010. At upwelling sites, pore-water oxygen concentrations dropped to hypoxic conditions below $4 \mathrm{~cm}$ sediment depth (Fig. 2). Iron oxide deposits indicated reducing conditions in the shallow subsurface at upwelling sites. However, stream sediments were well oxygenated at the two sites within each stream where sediment pore water was either a mixture of stream and ground water or downwelling stream water (Fig. 2). Pond water sampled at noon was supersaturated with oxygen and had a $\mathrm{pH}$ of 8.2 to 8.4 (Table 1).

Non-metric multidimensional scaling (NMDS) was used to identify relationships between DOC chemical properties $\left(\mathrm{SUVA}_{254}\right.$, molecular weight, carbohydrate concentration, $\delta^{13} \mathrm{C}$ values) of the four water types and microbial communities at days 7 and 70. NMDS was based on Bray-Curtis similarities. It was restricted to two dimensions. Data were transformed before the analysis by dividing response vari-

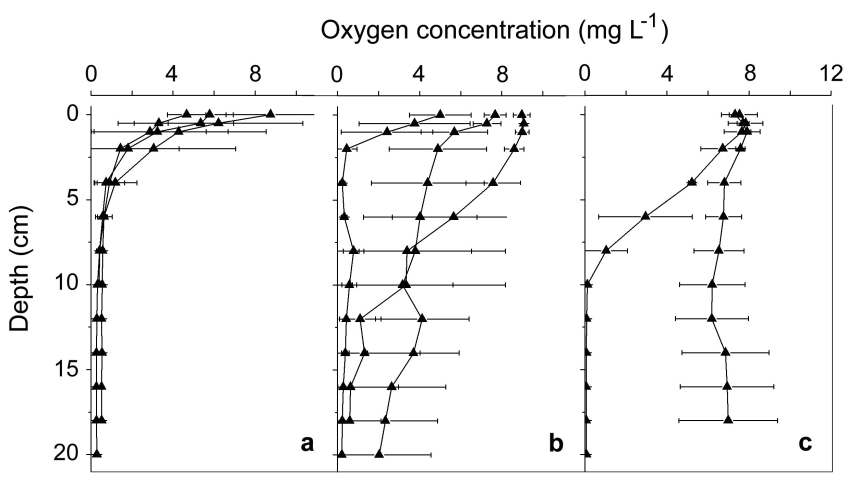

Fig. 2. Oxygen depth profiles in submerged stream sediments at sites were pore water was (a) upwelling ground water, (b) a mixture of stream and ground water, and (c) downwelling stream water (upstream of the alluvial fan) in the three main stream channels of the Chicken Creek Catchment. Symbols and error bars indicate means $\pm 1 \mathrm{SD}$ of three measurements made within areas of $10 \mathrm{~cm}^{2}$.

ables by their maxima, and treatments were standardized to equal sums. All calculations were performed with the software packages R (version 2.11.1; R Core Team, Vienna, Austria) and Origin Pro 9 (Origin Lab Corporation).

\subsection{DOC}

DOC concentrations significantly differed among water types along the hydrological flow path (one-factorial permANOVA: $\mathrm{MS}=$ mean sum of squares $=18.1, \quad \mathrm{df}=4$, $P<0.001$ ). Concentrations were highest in stream water (up to $20 \mathrm{mgL}^{-1}$, mean $\pm 95 \%$ confidence interval: $11.6 \pm 0.7 \mathrm{mg} \mathrm{L}^{-1}$ ) and lowest in soil solution $\left(6.0 \pm 0.5 \mathrm{mg} \mathrm{L}^{-1}\right.$ at 30 and $80 \mathrm{~cm}$ depth). Ground water $\left(7.5 \pm 0.5 \mathrm{mg} \mathrm{DOC} \mathrm{L}^{-1}\right)$ and pond water $(6.6 \pm 0.3 \mathrm{mg} \mathrm{DOC}$ $\mathrm{L}^{-1}$ ) had intermediate concentrations (Fig. 3). Mean DOC concentrations of the pond water between February and May significantly increased from 2008 to 2010 (one-factorial permANOVA: $\mathrm{MS}=6.37, \mathrm{df}=1, \quad P=0.03$ ); however, similar trends were not observed for soil solution, ground water or stream water.

In April 2010, mean DOC concentrations were similarly high in upwelling ground water, subsurface water and pond water, and tended to be slightly lower in soil solution (onefactorial permANOVA: $\mathrm{MS}=8.46, \mathrm{df}=3, P=0.21$; Table 2). DOC in soil solution and upwelling ground water showed large variability among the three replicates (coefficient of variation $=42$ and $48 \%$, respectively), which were taken more than $75 \mathrm{~m}$ apart from each other. The replicate sampling sites for subsurface water and pond water were located more closely together $(<20 \mathrm{~m})$ and coefficients of variation were as low as 8 and $14 \%$, respectively.

The ${ }^{14} \mathrm{C}$ values of groundwater DOC ranged between $-280 \%$ and $-297 \%$ o, corresponding to mean ${ }^{14} \mathrm{C}$ ages of $2635 \pm 35$ and $2830 \pm 40 \mathrm{yr}$ BP. The $\Delta^{14} \mathrm{C}$ values of the 
Table 1. Characteristics of soil solution, upwelling ground water, subsurface water and pond water of the Chicken Creek Catchment in April 2010. Soil solution was measured at $30 \mathrm{~cm}$ depth, upwelling ground water within the upper $4 \mathrm{~cm}$ of the stream sediment, and subsurface water at $60-70 \mathrm{~cm}$ sediment depth. Data for the pond water refer to a depth profile from 0 to $1.5 \mathrm{~m}$ in the pond water column. $\mathrm{n} . \mathrm{d}$. $=$ not determined.

\begin{tabular}{lrrrrrrr}
\hline Water type & $\begin{array}{r}\mathrm{O}_{2} \\
\left(\mathrm{mg} \mathrm{L}^{-1}\right)\end{array}$ & $\begin{array}{r}\mathrm{O}_{2} \\
(\%)\end{array}$ & $\begin{array}{r}\text { Temperature } \\
\left({ }^{\circ} \mathrm{C}\right)\end{array}$ & $\mathrm{pH}$ & $\begin{array}{r}\text { Conductivity } \\
\left(\mathrm{mS} \mathrm{cm}^{-1}\right)\end{array}$ & $n$ \\
\hline Soil solution & n.d. & n.d. & - & $12.5-13.0$ & $6.8-8.1$ & $0.23-0.53$ & 11 \\
Upwelling ground water & $0.7-8.8$ & $3-99$ & 45 & $12.8-14.3$ & $6.5-7.2$ & $0.53-2.12$ & 3 \\
Subsurface water & $2.5-5.2$ & $22-55$ & 3 & $10.2-11.6$ & $7.0-7.4$ & $0.89-1.05$ & 3 \\
Pond water & $11.7-14.1$ & $114-130$ & 20 & $12.2-14.7$ & $8.2-8.4$ & $0.60-0.62$ & 20 \\
\hline
\end{tabular}

Table 2. Chemical properties of DOC in soil solution, upwelling ground water, subsurface water and pond water of the Chicken Creek Catchment in April 2010. Data are means $\pm 1 \mathrm{SD}, n=3$. n.d. = not determined. Carbohydrates include monosaccharides (aldoses and ketoses) and oligo- and polysaccharides; concentrations are reported in $\mathrm{mg}$ glucose equivalents $\mathrm{L}^{-1}$.

\begin{tabular}{lrrrrr}
\hline Water type & $\begin{array}{r}\mathrm{DOC} \\
\left(\mathrm{mg} \mathrm{L}^{-1}\right)\end{array}$ & $\delta^{13} \mathrm{C}$ & $\begin{array}{r}\mathrm{SUVA}_{254} \\
\left(\mathrm{~L} \mathrm{mg}^{-1}\right.\end{array}$ & $\begin{array}{r}a_{250} / a_{365} \\
\text { ratio }\end{array}$ & $\begin{array}{r}\text { Carbohydrates } \\
\left(\mathrm{mg} \mathrm{L}^{-1}\right)\end{array}$ \\
\hline Soil solution & $6.2 \pm 2.7$ & n.d. & $5.9 \pm 0.7$ & $6.6 \pm 0.7$ & $0.1 \pm 0.2$ \\
Upwelling ground water & $9.8 \pm 3.7$ & $-27.4 \pm 0.7$ & $4.6 \pm 0.3$ & $8.3 \pm 1.3$ & $1.8 \pm 1.3$ \\
Subsurface water & $8.0 \pm 0.6$ & $-28.5 \pm 1.0$ & $4.4 \pm 0.5$ & $8.6 \pm 2.3$ & $0.6 \pm 0.2$ \\
Pond water & $9.7 \pm 1.5$ & $-29.0 \pm 0.7$ & $5.2 \pm 1.2$ & $7.8 \pm 0.4$ & $3.0 \pm 1.8$ \\
\hline
\end{tabular}

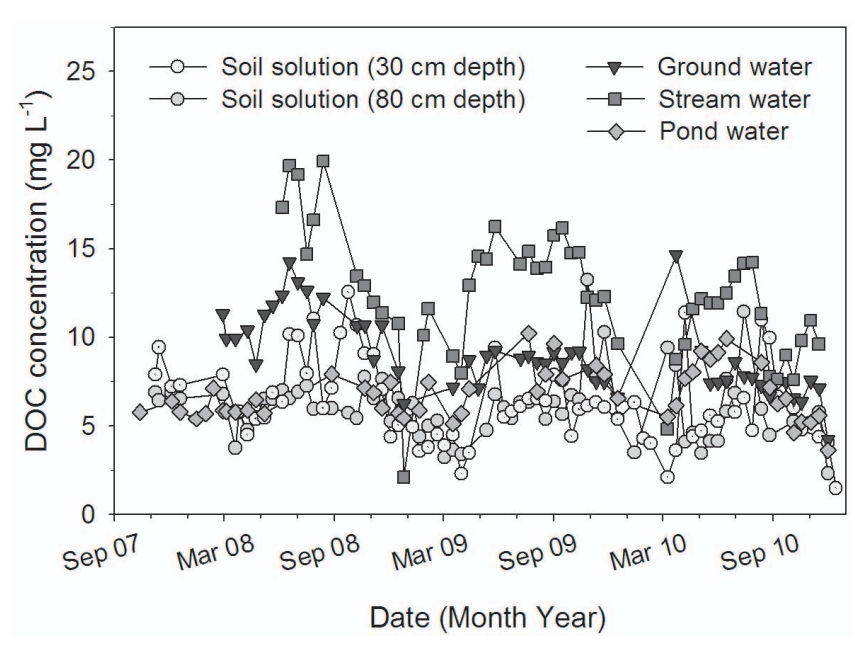

Fig. 3. Dynamics of DOC concentrations in soil solution at 30 and $80 \mathrm{~cm}$ depth, ground water, stream water, and pond water $(n=1)$. Results of Tukey's post hoc test $(P<0.05)$ for the period between February and May indicate that DOC concentrations in soil solution at $30 \mathrm{~cm}=$ soil solution at $80 \mathrm{~cm}=$ pond water $<$ stream water $=$ upwelling ground water.

Quaternary substrate were between $-317 \%$ and $-862 \%$, which corresponds to mean ${ }^{14} \mathrm{C}$ ages of $3065 \pm 45$ and $15935 \pm 75$ yr BP. According to a mixing model with Quaternary substrate and atmospheric $\mathrm{CO}_{2}$ as end-members (Eq. 3), the contribution of the Quaternary substrate to the DOC was $38 \%$ and $90 \%$, respectively. $\delta^{13} \mathrm{C}$ values of DOC decreased from $-27.4 \%$ to $-29.0 \%$ along the hydrological flow path (Table 2). Intensity distributions of DOC compounds observed by solid-state ${ }^{13} \mathrm{C}$ NMR spectra revealed that upwelling ground water and pond water differed in the composition of aromatic and $\mathrm{O}-/ \mathrm{N}-$ alkyl C (Fig. 4). DOC from the upwelling ground water showed higher proportions of aromatic C (32\%) than those from the pond water $(18 \%)$. Peaks at about $130 \mathrm{ppm}$ in both spectra indicated $\mathrm{C}$ - or H-substituted aromatic C (Knicker et al., 2005b). In contrast, DOC from the pond water had a higher proportion of O-/N-alkyl C. Resonances at about 72-74 ppm can be attributed to carbohydrate $\mathrm{C}$ in celluloses and hemicelluloses (Wilson et al., 1983). The proportion of alkyl $\mathrm{C}$ was similar at both sites. The signal at $31 \mathrm{ppm}$ in upwelling ground water indicated polymethylene $\mathrm{C}$ in long-chain aliphatic structures of varying origin (fatty acids, lipids, cutin acids and other aliphatic biopolymers). In contrast, DOC from the pond water showed a resonance at $23 \mathrm{ppm}$ caused by more short-chain alkyl $\mathrm{C}$ structures. These structures can be ascribed to acetyl groups in hemicelluloses (Kögel-Knabner, 1997, 2002). The proportion of carboxyl $\mathrm{C}$ was similar at both sites. These resonances at about $172 \mathrm{ppm}$ indicated carboxyl, amide and ester groups (Kögel-Knabner, 1997).

Total carbohydrate concentrations differed significantly among water types (one-factorial permANOVA: $\mathrm{MS}=5.19$, $\mathrm{df}=3, P=0.03)$. In agreement with the solid-state ${ }^{13} \mathrm{C}$ NMR spectra, the lowest concentration was recorded in soil solution and the highest in pond water (Table 2). Low-molecular-weight organic acids were mostly below the 


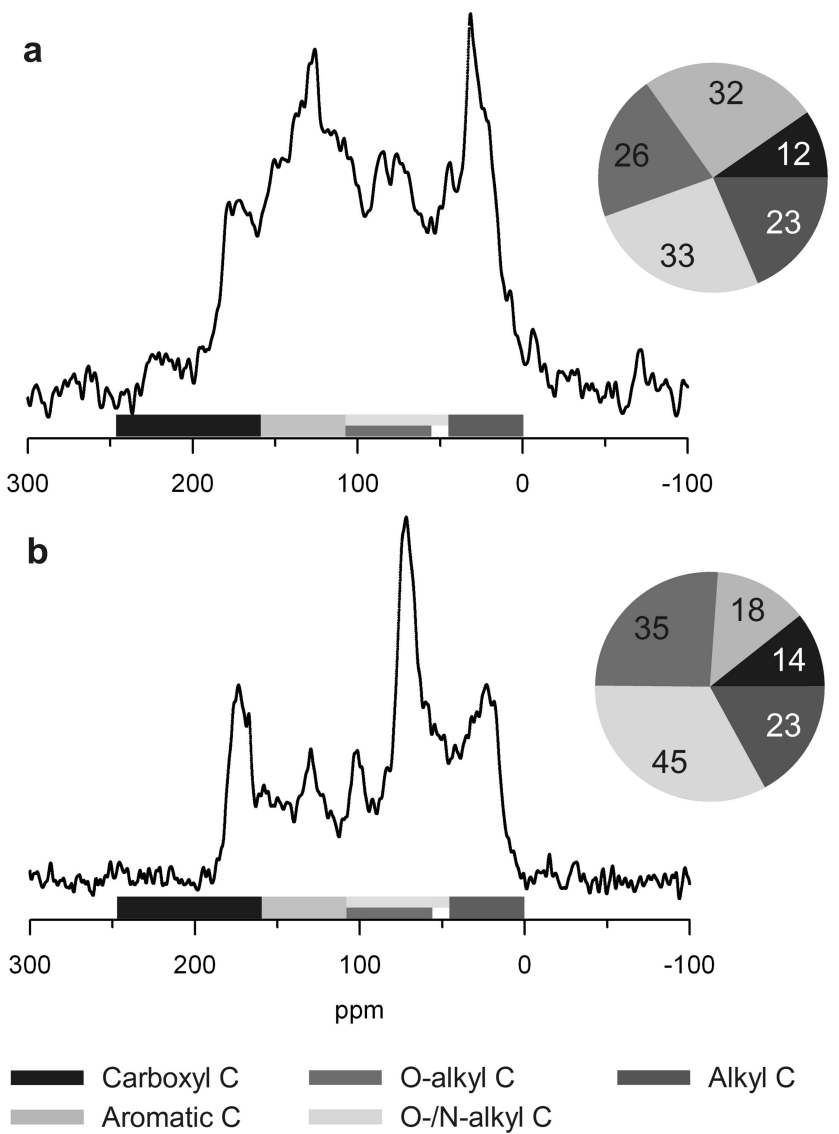

Fig. 4. Chemical composition of DOC revealed by solid-state CPMAS ${ }^{13} \mathrm{C}$ NMR spectroscopy from (a) upwelling ground water and (b) pond water $(n=1)$.

detection limit of $0.15 \mathrm{mg} \mathrm{L}^{-1}$ in all water types. $\mathrm{SUVA}_{254}$ (one-factorial permANOVA: $\mathrm{MS}=1.42 \times 10^{-4}, \mathrm{df}=3, P=$ 0.12 ) and the $a_{250} / a_{365}$ ratio (MS $=2.24, \mathrm{df}=3, P=0.36$ ) of all water types were similar along the hydrological flow path (Table 2).

\subsection{Bacterial abundance and DOC bioavailability}

Initial abundances of bacteria were one order of magnitude lower in water types inoculated with the stream microbial community compared to soil and pond water microbial communities. During the experimental incubation, the abundances and dynamics of suspended bacteria (Fig. 5) were similar among the three microbial communities used for inoculation (three-factorial permANOVA: $\mathrm{MS}=8.44 \times 10^{9}$, $\mathrm{df}=3, P=0.33)$ and they were also unaffected by water type $\left(\mathrm{MS}=9.43 \times 10^{9}, \mathrm{df}=3, P=0.27\right)$. Likewise, the density of biofilm bacteria was similar among the three microbial communities (two-factorial permANOVA: $\left.\mathrm{MS}=3.30 \times 10^{12}, \mathrm{df}=2, P=0.27\right)$ and among water types $\left(\mathrm{MS}=1.42 \times 10^{12}, \mathrm{df}=3, P=0.69\right)$. Abundances of sus-

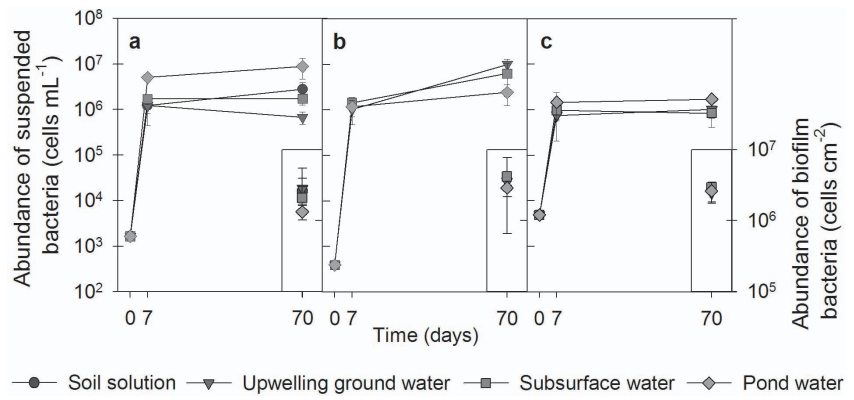

Fig. 5. Bacterial abundance in four types of water collected in the Chicken Creek Catchment and incubated for 70 days following inoculation with microbial communities from (a) soil, (b) stream sediment, and (c) pond water. Line plots represent suspended bacteria and inserted dot plots denote biofilm bacteria on glass slides exposed for 70 days. Symbols and error bars indicate means $\pm 1 \mathrm{SD}$, $n=3$.

pended bacteria increased 100 to 1000 fold within the first 7 days of the incubation and subsequently leveled off.

DOC in controls with deionized water increased from $0.9 \mathrm{mg} \mathrm{L}^{-1}$ to $2.2-3.7 \mathrm{mg} \mathrm{L}^{-1}$ following addition of the microbial inoculum and nutrient solution. No further temporal changes were observed over the next 70 days of incubation.

A significant effect of water type on DOC was caused by an overall lower DOC concentration in soil solution, whereas the three other water types did not significantly differ from one another. DOC dynamics, however, were statistically indistinguishable among the four water types, as revealed by non-significant interactions between water type and time as well as among water type, microbial community and time. DOC concentrations decreased until day 14 and remained constant thereafter (Fig. 6, Table 3). Although initial changes of DOC in subsurface water and pond water tended to diverge from those of soil solution and upwelling ground water, these tendencies were not statistically significant. Applying an exponential decay model to the data pooled across water types and microbial communities suggested that $11 \%$ of the DOC was bioavailable while $89 \%$ (95\% confidence interval: $0.05 \%$ ) was recalcitrant. The estimated decay rate coefficient of the bioavailable DOC fraction was 0.27 day $^{-1}$ ( $95 \%$ confidence interval: $0.85 \mathrm{day}^{-1}$ ), corresponding to a turnover time of 3.7 days (coefficient of determination of the exponential decay model $=0.15, n=50$ from which 7 outliers were removed).

Three-factorial permANOVA indicated that water type did not affect microbial respiration (Table 3). However, a significant interaction between microbial community and time indicated that the dynamics of respiration differed significantly among the three studied microbial communities during the incubation period. Respiration rates peaked during the first 14 days in all water types inoculated with soil and pond water microbial communities (Fig. 6). The stream microbial community showed a lower respiration rate at day 1 than both 
Table 3. Three-factorial permutation ANOVA (5000 permutations) testing for the effects of water type, microbial community, time and interactions of these factors on DOC concentration and microbial respiration. $\mathrm{df}=$ degrees of freedom; MS = mean sum of squares.

\begin{tabular}{lrrrrr}
\hline & & \multicolumn{2}{c}{ DOC } & \multicolumn{2}{c}{ Respiration } \\
\cline { 3 - 7 } Source of variation & df & MS & $P$ & MS & $P$ \\
\hline Water type & 3 & 17.3 & 0.04 & $1.8 \times 10^{-3}$ & 0.10 \\
Microbial community & 2 & 1.0 & 0.84 & $0.7 \times 10^{-3}$ & 0.48 \\
Time & 4 & 0.9 & 0.98 & $1.9 \times 10^{-3}$ & 0.07 \\
Water type $\times$ Microbial community & 1 & 1.5 & 0.61 & $1.6 \times 10^{-3}$ & 0.16 \\
Water type $\times$ Time & 3 & 2.1 & 0.80 & $0.9 \times 10^{-3}$ & 0.31 \\
Microbial community $\times$ Time & 2 & 0.9 & 0.84 & $4.7 \times 10^{-3}$ & 0.01 \\
Water type $\times$ Microbial & 4 & 0.6 & 0.98 & $0.2 \times 10^{-3}$ & 0.95 \\
community $\times$ Time & & & & & \\
Residuals & 130 & 5.9 & & $0.9 \times 10^{-3}$ & \\
\hline
\end{tabular}
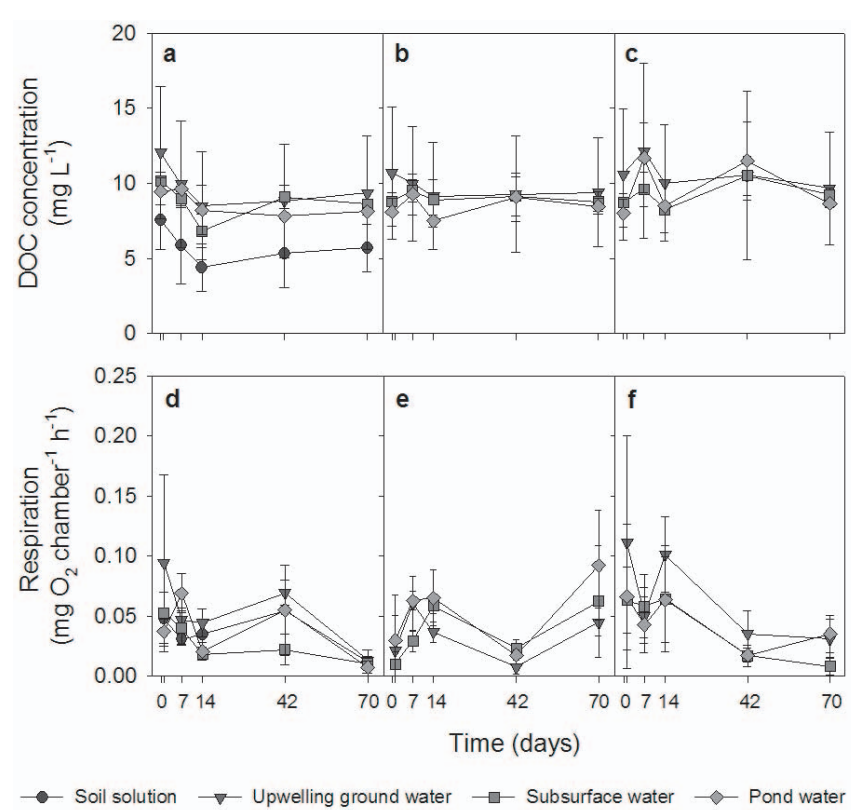

Fig. 6. Dynamics of (a), (b), (c) DOC concentrations and (d), (e), (f) microbial respiration during 70 days of incubation of four water types from the Chicken Creek Catchment inoculated with microbial communities from (a), (d) soil; (b), (e) stream sediment; and (c), (f) pond water. Microbial respiration data are the sum of oxygen consumption per hour in one respiration chamber containing $47 \mathrm{~mL}$ suspensions and $11.9 \mathrm{~cm}^{2}$ of biofilm. Symbols and error bars indicate means $\pm 1 \mathrm{SD}, n=3$. For statistical analyses see Table 3 .

other communities, possibly caused by bacterial abundances that were initially 10 times lower. Microbial communities from soil, stream sediment and pond water showed decreasing respiration rates after either day 42 or day 14 . In contrast to the soil and pond water communities, respiration of the stream sediment community increased to the initial level on day 70. Microbial respiration was not related to DOC concentration $(R=0.08, P=0.41)$.
Water type and microbial community also affected the chemical properties of DOC during the incubation. The microbial communities of soil, stream sediment and pond water used $8.6 \%$ (perm $t$ test: $P=0.83), 33.1 \%(P=0.05)$ and $36.8 \%(P=0.10)$ of the pond water carbohydrates between days 7 and 70, respectively (Fig. 7). The $\delta^{13} \mathrm{C}$ DOC between days 7 and 70 was significantly affected by water type (two-factorial permANOVA: $\mathrm{MS}=1.09, \mathrm{df}=3, P=$ 0.004 ) but not by the microbial community (MS $=0.03$, $\mathrm{df}=2, P=0.87)$. The estimated isotopic difference ranged from 0.9 to $2.2 \%$ between days 7 and 70 . The smallest differences were detected in soil solution and pond water. Larger isotopic differences between days 7 and 70 were observed in upwelling ground water and subsurface water; they might be attributable to changes in aromaticity and molecular weight of the DOC over time (Fig. 7). The $a_{250} / a_{365}$ ratio increased in both water types from day 7 to 70 , indicating a shift towards low-molecular-weight compounds. SUVA $_{254}$ decreased when the microbial community of stream sediments was used as inoculum, but increased when the pond water microbial community was used. Inoculation with the soil microbial community had no effect on $\mathrm{SUVA}_{254}$ in either water type. Pond water inoculated with the soil and pond water microbial communities had higher $\mathrm{SUVA}_{254}$ at day 70 than at day 7 .

\subsection{DOC fluxes}

Our flux estimates indicate DOC input from the catchment into the pond of $63-248 \mathrm{~kg} \mathrm{yr}^{-1}$ with large variation among years (Table 4). The highest input was measured in 2010 when precipitation $(794 \mathrm{~mm})$ and hence surface flow in the streams were greater than in 2008 and 2009 (annual precipitation: $660 \mathrm{~mm}$ and $665 \mathrm{~mm}$, respectively). In general, the DOC exported from the catchment at the pond outlet was substantially smaller than the estimated input via wet deposition, stream water, ground water and subsurface water, indicating net DOC removal in the pond. The estimated net 
Table 4. DOC flux estimates into and out of the pond in the Chicken Creek Catchment between 2008 and 2010. Aerial estimates were based on a pond surface area of $4000 \mathrm{~m}^{2}$.

\begin{tabular}{rrrrrrrr}
\hline Year & $\begin{array}{r}\text { Input via } \\
\text { wet } \\
\text { deposition } \\
\left(\mathrm{kg} \mathrm{yr}^{-1}\right)\end{array}$ & $\begin{array}{r}\text { Input via stream, } \\
\text { ground and } \\
\text { subsurface water } \\
\left(\mathrm{kg} \mathrm{yr}^{-1}\right)\end{array}$ & $\begin{array}{r}\text { Export from the } \\
\text { catchment }\end{array}$ & & & Removal in pond \\
$\left(\mathrm{kg} \mathrm{yr}^{-1}\right)$ & $(\%$ of input $)$ & $\left(\mathrm{kg} \mathrm{yr}^{-1}\right)$ & $\left(\mathrm{g} \mathrm{m}^{-2} \mathrm{yr}^{-1}\right)$ & $(\%$ of input $)$ \\
\hline 2008 & 5.3 & 63 & 31 & 45 & 37 & 9 & 54 \\
2009 & 4.8 & 104 & 72 & 66 & 37 & 9 & 34 \\
2010 & 3.4 & 248 & 174 & 69 & 77 & 19 & 31 \\
\hline
\end{tabular}

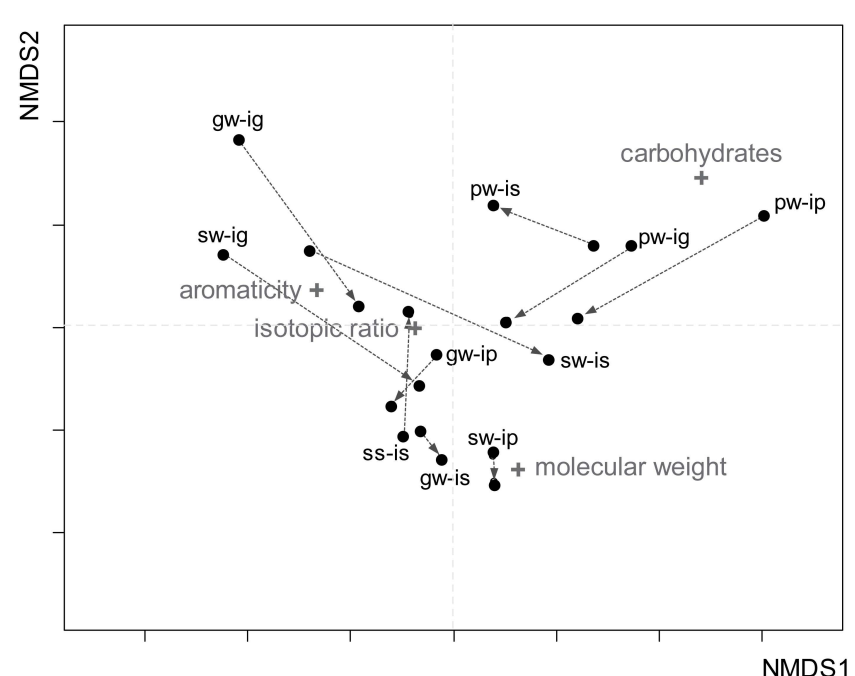

Fig. 7. Two-dimensional ordination plot of nMDS based on BrayCurtis similarities of mean carbohydrate concentration, $\mathrm{SUVA}_{254}$, molecular weight and isotopic ratio of DOC from four water types of the Chicken Creek Catchment incubated with three microbial communities for 7 and 70 days (mean, $n=3$ ). Gray arrows indicate major changes in DOC chemical properties and point from day 7 towards day 70; ss - soil solution, gw - upwelling ground water, $\mathrm{sw}$ - subsurface water of the alluvial fan, pw - pond water, is - soil microbial community, ig - stream-sediment microbial community, ip - pond-water microbial community.

DOC removal (Eq. 5) amounted to 37 to $77 \mathrm{~kg} \mathrm{yr}^{-1}$ (Table 4), which corresponds to an annual DOC removal in the pond of $9 \mathrm{~g} \mathrm{~m}^{-2}$ in 2008 and of $19 \mathrm{~g} \mathrm{~m}^{-2}$ in 2010 . DOC export from the catchment increased from $45 \%$ to $69 \%$ between 2008 and 2010, whereas the proportional DOC removal in the pond decreased from $54 \%$ to $31 \%$ (Table 4 ).

\section{Discussion}

DOC concentrations in the recently constructed Chicken Creek Catchment with sparse vegetation cover and minimal soil development were surprisingly high. The measured concentrations of up to $7 \mathrm{mg} \mathrm{L}^{-1}$ in soil solution are similar to those of mineral soils in temperate grasslands and forests
(Fahey et al., 2005; Nambu et al., 2008; Sanderman et al., 2008; Tipping et al., 2012). Likewise, DOC concentrations in ground water, surface waters and subsurface water with up to $20 \mathrm{mg} \mathrm{DOC} \mathrm{L}^{-1}$ are similar to, or even higher than, those of mature ecosystems, including streams (Ziegler and Brisco, 2004), lakes (Pace and Cole, 2002; Steinberg, 2003; Berggren et al., 2009), and forest and grassland catchments (e.g., Hagedorn et al., 2000).

Radiocarbon ages of the $\mathrm{C}$ in the Quaternary substrate and groundwater DOC indicate that the Quaternary substrate contributed about 40 to $90 \%$ to the DOC in the ground water of the Chicken Creek Catchment. The calculated contributions of this "old" carbon from the Quaternary substrate are likely to be underestimates. The reason is that DOC leached from substrates is usually younger than the substrate itself, because the younger carbon components tend to be preferentially released (Fröberg et al., 2003; Sanderman et al., 2008). Additional uncertainty arises from the $\Delta^{14} \mathrm{C}$ values of the Quaternary substrate used to construct the catchment with unknown contributions of charred and hence " $14 \mathrm{C}$ dead" components (i.e., components with a $\Delta^{14} \mathrm{C}$ value of $1000 \%$ o because the age exceeds $50000 \mathrm{yr}$; Arnold and Libby, 1949) and more recent carbon originating from vegetation grown on the substrate before it was used for constructing the experimental Chicken Creek Catchment.

The relatively high average ${ }^{14} \mathrm{C}$ age of DOC in the Chicken Creek Catchment (about 2600 to 2900 yr BP) is consistent with data from other early successional ecosystems in glacier forefields. For instance, stream water DOC supplied by melting glaciers of partly deglaciated catchments in Alaska has radiocarbon ages of up to $4000 \mathrm{yr} \mathrm{BP}\left(\Delta^{14} \mathrm{C}\right.$ values: 0 $400 \%$; Hood et al., 2009). Similarly, the ${ }^{14} \mathrm{C}$ age of DOC in glacier-fed streams in the European Alps ranged between 600 and $6800 \mathrm{yr}$ BP (Singer et al., 2012). Both studies noted a positive relationship between the ${ }^{14} \mathrm{C}$ age and the bioavailable fraction of the DOC (Hood et al., 2009; Singer et al., 2012). The estimated fractions of bioavailable DOC in the glacier-fed streams was $20 \%$ for recent DOC and $95 \%$ for old DOC, implying that old carbon can be a significant substrate for microbial heterotrophs in surface waters of earlysuccessional ecosystems. 
Changes in DOC concentrations and microbial respiration during our 70 day experimental incubations of different types of water from the Chicken Creek Catchment suggest two distinct periods: an initial period characterized by declining DOC concentrations and relatively high respiration rates between days 0 and 14 , and a second period between days 14 and 70 when changes in DOC concentration were minor (Fig. 6). The initial sharp decline in DOC is in accordance with data from a wide range of soil solutions (Kalbitz et al., 2003), and suggests that about $11 \%$ of the DOC was bioavailable. In mature ecosystems, including forests, agricultural soils, streams, rivers and wetlands, the bioavailable fraction of DOC has been found to range from 3 to $67 \%$, with a mean of $25 \%$ (e.g., Raymond and Bauer, 2001; Wiegner and Seitzinger, 2001; Marschner and Kalbitz, 2003; Wiegner et al., 2006; Balcarczyk et al., 2009; Hood et al., 2009; Petrone et al., 2009). Thus, despite the sparse vegetation and soil development, the proportion of bioavailable carbon in DOC of the early-successional Chicken Creek Catchment is similar to that of mature ecosystems (although smaller than that in early-successional glacier-fed catchments as discussed above; Hood et al., 2009; Singer et al., 2012).

One reason for the lower DOC bioavailability in the Chicken Creek Catchment compared to other earlysuccessional catchments might be the release of highly aromatic DOC from charred material in the Quaternary substrate. The solid-state ${ }^{13} \mathrm{C}$ NMR peaks observed at about $130 \mathrm{ppm}$ are commonly assigned to aromatic carbon derived from charred organic material such as lignite, soot, or altered plant-derived lignin (Skjemstad et al., 1996; Knicker et al., 2005a). Given that sources of plant-derived lignin were scarce in the catchment (Schaaf et al., 2012), the observed degree of aromaticity was most probably due to older material. Part of the long-chain aliphatic carbon in the DOC, as represented by alkyl C, could also have originated from old material such as lignite (Rumpel et al., 1998). Thus, it appears that part of the DOC in the Chicken Creek Catchment was mobilized from the Quaternary substrate. This mobilization could have been facilitated by the dumping process during catchment construction when disturbance of the Quaternary substrates could have triggered processes resulting in DOC release. Potential processes include exposure of previously protected mineral surfaces, desorption of soil organic carbon, and stimulation of microbial activity by altering aeration and substrate availability. As a result, DOC concentrations in soil and surface waters of the Chicken Creek Catchment were much higher than in some natural early-successional catchments such as the glacier forefields studied by Hood et al. (2009) and Guelland et al. (2013).

Sorption to (and desorption from) mineral phases, leaching from patchily distributed vegetation and leaf litter as well as microbial activities in the subsurface may alter the chemical properties and composition of DOC along the hydrological flow path. This trend was also observed in the Chicken
Creek Catchment, from sites of upwelling ground water to subsurface waters of the alluvial fan, although DOC concentrations varied little. The tendency of total carbohydrate concentrations to decrease points to mineralization in the welloxygenated hyporheic zone of the streams, where carbon is mineralized by microbial communities (Gerull et al., 2011). This is in line with the observed ${ }^{13} \mathrm{C}$ depletion of DOC $(1.1$ to $1.6 \%$ ) along the hydrological flow path, suggesting preferential microbial degradation or sorption of ${ }^{13} \mathrm{C}$-enriched compounds such as recently formed carbohydrates (Benner et al., 1987; Santruckova et al., 2000).

DOC in pond water was distinctly different from that in all other water types in that the carbohydrate concentration was greater, the proportion of $\mathrm{O}-/ \mathrm{N}-a l k y l ~ C$ was markedly higher, and the proportion of aromatic $\mathrm{C}$ was lower. These characteristics might be attributed to a significant organic carbon supply by aquatic primary producers. Potential sources include phytoplankton, submerged macrophytes, which developed dense stands in the pond (Elmer et al., 2011), and litter leachates from Phragmites australis, a highly productive emergent macrophyte that rapidly colonized the pond margins. Biological soil crusts covering large parts of the catchment (Fischer et al., 2010) and the accumulation of plant litter during early ecosystem succession may have been additional sources of recent DOC, since the pond received water mostly via surface runoff collected in stream channels during heavy precipitation (Elmer et al., 2013; Hofer et al., 2012).

Total DOC concentration was not related to the fraction of bioavailable DOC in the Chicken Creek Catchment, which is in accordance with previous findings (Findlay et al., 2001; Sobczak and Findlay, 2002; Wiegner et al., 2006). However, DOC bioavailability is affected by its quality as defined by chemical properties. Carbohydrates are preferentially used over organic carbon containing high proportions of aromatic groups, including humic substances (Baldock et al., 1997; Kalbitz et al., 2003; Ziegler and Brisco, 2004), and recalcitrant, high-molecular weight DOC can even inhibit microbial activity (Freeman and Lock, 1992). Given a higher proportion of carbohydrates and a lower proportion of aromatics in pond water, we expected pond water DOC to be more readily bioavailable for microbial metabolism than DOC from other water types. However, this expectation was not met in the present study in that DOC bioavailability was similar across all water types (Fig. 6, Table 3). Nevertheless, a larger fraction of carbohydrates was utilized in the pond water than in soil solution, upwelling ground water or subsurface water of the alluvial fan (Fig. 7). Since carbohydrates can bind to aromatic C compounds of refractory DOC (Jandl and Sollins, 1997), aromatic C might have protected carbohydrates from microbial use in the last three types of water, leading to a smaller decline in concentration than in pond water. As a result, our incubations of those three water types mainly affected DOC aromaticity and molecular weight (Fig. 7). Thus, although the proportion of bioavailable DOC in the different water types of the Chicken Creek Catchment was similar, it 
appears that different DOC fractions were used by the microbial communities.

Systematic changes of DOC composition along hydrological flow paths can lead to adapted microbial communities (Myers et al., 2001; Judd and Kling, 2002; Zak et al., 2003), which utilize the available DOC pools differentially. Consequently, we expected microbial communities of different origins to differ in their ability to remove DOC from the different water types collected along the hydrological flow path in the Chicken Creek Catchment. However, this hypothesis was not supported by the data of our 70 day experimental incubations where inoculation with all microbial communities led to a similar use of DOC from the different water types, suggesting that, as a whole, the natural microbial communities along the hydrological flow path of the Chicken Creek Catchment had similar physiological capabilities.

The estimated DOC input into the pond by wet deposition, ground water, stream water, and subsurface water (17 to $63 \mathrm{~g}$ $\mathrm{DOC} \mathrm{m}{ }^{-2} \mathrm{yr}^{-1}$ ) is within the range of mature ecosystems (e.g., Hagedorn et al., 2000; Raymond and Saiers, 2010). In the pond, the DOC mass balance suggests a net removal of the received DOC in the order of 30 to $50 \%$. This is more than can be accounted for by microbial use, given that on average only $11 \%$ of the DOC was found to be bioavailable during our 70 day experimental incubation. Potential reasons for this discrepancy could be photomineralization, flocculation (e.g., von Wachenfeldt and Tranvik, 2008) or adsorption of DOC to mineral surfaces. Additionally, periphytic and benthic bacterial communities present in the pond might be more effective at utilizing the imported DOC than the bacterial communities, both suspended and attached, present during our experimental incubation. Irrespective of the predominant removal processes, it is clear that substantially more DOC was removed in the pond than implied by our mass balance, because phytoplankton and macrophytes generated additional DOC within the pond that was not considered in our mass balance calculation. Detailed measurements taking account of within-pond DOC release and microbial carbon utilization and fate, both in the pond water column and other ecosystem compartments would be needed to refine our budget and identify the principal mechanisms responsible for the observed DOC removal in the pond.

Acknowledgements. This study is part of the Transregional Collaborative Research Centre 38 (SFB/TRR 38), which was financially supported by the Deutsche Forschungsgemeinschaft (DFG, Bonn) and the Brandenburg Ministry of Science, Research and Culture (MWFK, Potsdam). The authors thank Vattenfall Europe Mining AG for providing the research site; R. Ender, T. Wolburg, G. Franke, K. Felsmann, M. Stange and R. Nenov for technical support in the field and laboratory; and M. Knie and C. Mendoza Lera for helpful discussions.

Edited by: J.-A. Subke

\section{References}

Ågren, A., Berggren, M., Laudon, H., and Jansson, M.: Terrestrial export of highly bioavailable carbon from small boreal catchments in spring floods, Freshw. Biol., 53, 964-972, 2008.

Anderson, M. J.: Permutation tests for univariate or multivariate analysis of variance and regression, Can. J. Fish. Aquat. Sci., 58, 626-639, 2001.

Arnold, J. R. and Libby, W. F.: Age determinations by radiocarbon content: Checks with samples of known age, Science, 110, 678680, 1949.

Balcarczyk, K. L., Jones, J. B., Jaffe, R., and Maie, N.: Stream dissolved organic matter bioavailability and composition in watersheds underlain with discontinuous permafrost, Biogeochemistry, 94, 255-270, 2009.

Baldock, J. A., Oades, J. M., Nelson, P. N., Skene, T. M., Golchin, A., and Clarke, P.: Assessing the extent of decomposition of natural organic materials using solid-state ${ }^{13} \mathrm{C}$ NMR spectroscopy, Aust. J. Soil Res., 35, 1061-1083, 1997.

Bardgett, R. D. and Walker, L. R.: Impact of coloniser plant species on the development of decomposer microbial communities following deglaciation, Soil Biol. Biochem., 36, 555-559, 2004.

Battin, T. J., Kaplan, L. A., Findlay, S., Hopkinson, C. S., Martí, E., Packman, A. I., Newbold, J. D., and Sabater, F.: Biophysical controls on organic carbon fluxes in fluvial networks, Nat. Geosci., 1, 95-100, 2008.

Benner, R., Fogel, M. L., Sprague, E. K., and Hodson, R. E.: Depletion of C-13 in lignin and its implications for stable carbon isotope studies, Nature, 329, 708-710, 1987.

Berggren, M., Laudon, H., and Janssona, M.: Aging of allochthonous organic carbon regulates bacterial production in unproductive boreal lakes, Limnol. Oceanogr., 54, 1333-1342, 2009.

Bernasconi, S. M., Bauder, A., Bourdon, B., Brunner, I., Bünemann, E., Chris, I., Derungs, N., Edwards, P., Farinotti, D., Frey, B., Frossard, E., Furrer, G., Gierga, M., Göransson, H., Gülland, K., Hagedorn, F., Hajdas, I., Hindshaw, R., Ivy-Ochs, S., Jansa, J., Jonas, T., Kiczka, M., Kretzschmar, R., Lemarchand, E., Luster, J., Magnusson, J., Mitchell, E. A. D., Venterink, H. O., Plötze, M., Reynolds, B., Smittenberg, R. H., Stähli, M., Tamburini, F., Tipper, E. T., Wacker, L., Welc, M., Wiederhold, J. G., Zeyer, J., Zimmermann, S., and Zumsteg, A.: Chemical and biological gradients along the Damma Glacier soil chronosequence, Switzerland, Vadose Zone J., 10, 867-883, 2011.

de Haan, H. and de Boer, T.: Applicability of light absorbance and fluorescence as measures of concentration and molecular size of dissolved organic carbon in humic Lake Tjeukemeer, Water Res., 21, 731-734, 1987.

Dubois, M., Gilles, K. A., Hamilton, J. K., Rebers, P. A., and Smith, F.: Colorimetric method for determination of sugars and related substances, Anal. Chem., 28, 350-356, 1956.

Elmer, M., Schaaf, W., Biemelt, D., Gerwin, W., and Hüttl, R. F.: Ecosystem Development. The artificial catchment Chicken Creek - Initial ecosystem development 2005-2010, Brandenburg University of Technology Cottbus, Cottbus, ISSN 1867-7800, 168 pp., 2011.

Elmer, M., Gerwin, W., Schaaf, W., Zaplata, M. K., Hohberg, K., Nenov, R., Bens, O., and Hüttl, R. F.: Dynamics of initial ecosystem development at the artificial catchment Chicken Creek, Lusatia, Germany. Environ. Earth Sci., 69, 491-505, 2013. 
Fahey, T. J., Siccama, T. G., Driscoll, C. T., Likens, G. E., Campbell, J., Johnson, C. E., Battles, J. J., Aber, J. D., Cole, J. J., Fisk, M. C., Groffman, P. M., Hamburg, S. P., Holmes, R. T., Schwarz, P. A., and Yanai, R. D.: The biogeochemsitry of carbon at Hubbard Brook, Biogeochemistry, 75, 109-176, 2005.

Fiebig, D. M. and Marxsen, J.: Immobilization and mineralization of dissolved free amino-acids by stream-bed biofilms, Freshw. Biol., 28, 129-140, 1992.

Findlay, S. E. G., Quinn, J. M., Hickey, C. W., Burrell, G., and Downes, M.: Effects of land use and riparian flowpath on delivery of dissolved organic carbon to streams, Limnol. Oceanogr., 46, 345-355, 2001.

Findlay, S. E. G., Sinsabaugh, R. L., Sobczak, W. V., and Hoostal, M.: Metabolic and structural response of hyporheic microbial communities to variations in supply of dissolved organic matter, Limnol. Oceanogr., 48, 1608-1617, 2003.

Fischer, T., Veste, M., Schaaf, W., Dümig, A., Kögel-Knabner, I., Wiehe, W., Bens, O., and Hüttl, R. F.: Initial pedogenesis in a topsoil crust 3 years after construction of an artificial catchment in Brandenburg, NE Germany, Biogeochemistry, 101, 165-176, 2010.

Freeman, C. and Lock, M. A.: Recalcitrant high-molecular-weight material, an inhibitor of microbial metabolism in river biofilms, Appl. Environ. Microb., 58, 2030-2033, 1992.

Fröberg, M., Berggren, D., Bergkvist, B., Bryant, C., and Knicker, H.: Contributions of Oi, Oe and Oa horizons to dissolved organic matter in forest floor leachates, Geoderma, 113, 311-322, 2003.

Gerull, L., Frossard, A., Gessner, M. O., and Mutz, M.: Variability of heterotrophic metabolism in small stream corridors of an early successional watershed, J. Geophys. Res., 116, G02012, doi:10.1029/2010JG001516, 2011.

Gerwin, W., Schaaf, W., Biemelt, D., Fischer, A., Winter, S., and Hüttl, R. F.: The artificial catchment "Chicken Creek" (Lusatia, Germany) - A landscape laboratory for interdisciplinary studies of initial ecosystem development, Ecol. Eng., 35, 1786-1796, 2009.

Gerwin, W., Schaaf, W., Biemelt, D., Winter, S., Fischer, A., Veste, M., and Hüttl, R. F.: Overview and first results of ecological monitoring at the artificial watershed Chicken Creek (Germany), Phys. Chem. Earth, 36, 61-73, 2011.

Guelland, K., Hagedorn, F., Smittenberg, R. H., Göransson, H., Bernasconi, S. M., Hajdas, I., and Kretzschmar, R.: Evolution of carbon fluxes during initial soil formation along the forefield of Damma glacier, Switzerland, Biogeochemistry, 113, 545-561, 2013.

Hagedorn, F., Schleppi, P., Waldner, P., and Flühler, H.: Export of dissolved organic carbon and nitrogen from Gleysol dominated catchments - The significance of water flow paths, Biogeochemistry, 50, 137-161, 2000.

Hofer, M., Lehmann, P., Stähli, M., Seifert, S., and Krafczyk, M.: Two approaches to modeling the initiation and development of rills in a man-made catchment, Water Resour. Res., 48, W01531, doi:10.1029/2011WR010719, 2012.

Hood, E., Fellman, J., Spencer, R. G. M., Hernes, P. J., Edwards, R., D'Amore, D., and Scott, D.: Glaciers as a source of ancient and labile organic matter to the marine environment, Nature, 462, 1044-1048, 2009.

Jandl, R. and Sollins, P.: Water extractable soil carbon in relation to the belowground carbon cycle, Biol. Fert. Soils, 25, 196-201,
1997.

Judd, K. E. and Kling, G. W.: Production and export of dissolved $\mathrm{C}$ in arctic tundra mesocosms: The roles of vegetation and water flow, Biogeochemistry, 60, 213-234, 2002.

Judd, K. E., Crump, B. C., and Kling, G. W.: Variation in dissolved organic matter controls bacterial production and community composition, Ecology, 87, 2068-2079, 2006.

Kaiser, K., Guggenberger, G., Haumaier, L., and Zech, W.: The composition of dissolved organic matter in forest soil solutions: Changes induced by seasons and passage through the mineral soil, Org. Geochem., 33, 307-318, 2002.

Kalbitz, K., Solinger, S., Park, J. H., Michalzik, B., and Matzner, E.: Controls on the dynamics of dissolved organic matter in soils: A review, Soil. Sci., 165, 277-304, 2000.

Kalbitz, K., Schmerwitz, J., Schwesig, D., and Matzner, E.: Biodegradation of soil-derived dissolved organic matter as related to its properties, Geoderma, 113, 273-291, 2003.

Knicker, H. and Lüdemann, H.-D.: N-15 and C-13 CPMAS and solution NMR studies of $\mathrm{N}-15$ enriched plant material during 600 days of microbial degradation, Org. Geochem., 23, 329-341, 1995.

Knicker, H., González-Vila, F. J., Polvillo, O., González, J. A., and Almendros, G.: Fire-induced transformation of C- and Nforms in different organic soil fractions from a Dystric Cambisol under a Mediterranean pine forest (Pinus pinaster), Soil Biol. Biochem., 37, 701-718, 2005a.

Knicker, H., Totsche, K. U., Almendros, G., and González-Vila, F. J.: Condensation degree of burnt peat and plant residues and the reliability of solid-state VACP MAS ${ }^{13} \mathrm{C}$ NMR spectra obtained from pyrogenic humic material, Org. Geochem., 36, 1359-1377, 2005b.

Kögel-Knabner, I.: ${ }^{13} \mathrm{C}$ and ${ }^{15} \mathrm{~N}$ NMR spectroscopy as a tool in soil organic matter studies, Geoderma, 80, 243-270, 1997.

Kögel-Knabner, I.: The macromolecular organic composition of plant and microbial residues as inputs to soil organic matter, Soil Biol. Biochem., 34, 139-162, 2002.

Le Dû-Delepierre, A., Persoone, G., and Grolière, C. A.: A new low cost microbiotest with the freshwater ciliate protozoan Spirostomum ambiguum - Definition of culturing conditions, Hydrobiologia, 325, 121-130, 1996.

Marschner, B. and Kalbitz, K.: Controls of bioavailability and biodegradability of dissolved organic matter in soils, Geoderma, 113, 211-235, 2003.

McDowell, W. H.: Kinetics and mechanisms of dissolved organiccarbon retention in a headwater stream, Biogeochemistry, 1, 329-352, 1985.

McKnight, D. M., Bencala, K. E., Zellweger, G. W., Aiken, G. R., Feder, G. L., and Thorn, K. A.: Sorption of dissolved organic carbon by hydrous aluminum and iron oxides occurring at the confluence of Deer Creek with the Snake River, Summit County, Colorado, Environ. Sci. Technol., 26, 1388-1396, 1992.

Meier, M., Namjesnik-Dejanovic, K., Maurice, P. A., Chin, Y. P., and Aiken, G. R.: Fractionation of aquatic natural organic matter upon sorption to goethite and kaolinite, Chem. Geol., 157, 275284, 1999.

Myers, R. T., Zak, D. R., White, D. C., and Peacock, A.: Landscapelevel patterns of microbial community composition and substrate use in upland forest ecosystems, Soil Sci. Soc. Am. J., 65, 359367, 2001. 
Nambu, K., van Hees, P. A. W., Jones, D. L., Vinogradoff, S., and Lundström, U. S.: Composition of organic solutes and respiration in soils derived from alkaline and non-alkaline parent materials, Geoderma, 144, 468-477, 2008.

Nii-Annang, S., Grünewald, H., Freese, D., Hüttl, R. F., and Dilly, O.: Microbial activity, organic $\mathrm{C}$ accumulation and ${ }^{13} \mathrm{C}$ abundance in soils under alley cropping systems after 9 years of recultivation of quaternary deposits, Biol. Fertil. Soils, 45, 531-538, 2009.

Nixdorf, B. and Jander, J.: Bacterial activities in shallow lakes A comparison between extremely acidic and alkaline eutrophic hard water lakes, Hydrobiologia, 506-509, 697-705, 2003.

Pace, M. L. and Cole, J. J.: Synchronous variation of dissolved organic carbon and color in lakes, Limnol. Oceanogr., 47, 333-342, 2002.

Peersen, O. B., Wu, X., Kustanovich, I., and Smith, S. O.: Variableamplitude cross-polarization MAS NMR, J. Magn. Reson., 104, 334-339, 1993.

Petrone, K. C., Richards, J. S., and Grierson, P. F.: Bioavailability and composition of dissolved organic carbon and nitrogen in a near coastal catchment of south-western Australia, Biogeochemistry, 92, 27-40, 2009.

Ramsey, C. B.: Development of the radiocarbon calibration program, Radiocarbon, 43, 355-363, 2001.

Raymond, P. A. and Bauer, J. E.: Riverine export of aged terrestrial organic matter to the North Atlantic Ocean, Nature, 409, 497500, 2001

Raymond, P. A. and Saiers, J. E.: Event controlled DOC export from forested watersheds, Biogeochemistry, 100, 197-209, 2010.

Romaní, A. M., Vazquez, E., and Butturini, A.: Microbial availability and size fractionation of dissolved organic carbon after drought in an intermittent stream: Biogeochemical link across the stream-riparian interface, Microb. Ecol., 52, 501-512, 2006.

Rumpel, C., Knicker, H., Kögel-Knabner, I., Skjemstad, J. O., and Hüttl, R. F.: Types and chemical composition of organic matter in reforested lignite-rich mine soils, Geoderma, 86, 123-142, 1998.

Sanderman, J., Baldock, J. A., and Amundson, R.: Dissolved organic carbon chemistry and dynamics in contrasting forest and grassland soils, Biogeochemistry, 89, 181-198, 2008.

Santruckova, H., Bird, M. I., and Lloyd, J.: Microbial processes and carbon-isotope fractionation in tropical and temperate grassland soils, Funct. Ecol., 14, 108-114, 2000.

Schaaf, W., Bens, O., Fischer, A., Gerke, H. H., Gerwin, W., Grünewald, U., Hollander, H. M., Kögel-Knabner, I., Mutz, M., Schloter, M., Schulin, R., Veste, M., Winter, S., and Hüttl, R. F.: Patterns and processes of initial terrestrial ecosystem development, J. Plant Nutr. Soil Sc., 174, 229-239, 2011.

Schaaf, W., Elmer, M., Fischer, A., Gerwin, W., Nenov, R., Pretzsch, H., Seifert, S., Winter, S., and Zaplata, M. K.: Monitoring the formation of structures and patterns during initial development of an artificial catchment, Environ. Monit. Assess., 185, 5965-5986, doi:10.1007/s10661-012-2998-x, 2012.

Schaefer, J. and Stejskal, E. O.: Carbon-13 nuclear magnetic resonance of polymers spinning at magic angle, J. Am. Chem. Soc., 98, 1031-1032, 1976.

Schlief, J. and Mutz, M.: Leaf decay processes during and after a supra-seasonal hydrological drought in a temperate lowland stream, Internat. Rev. Hydrobiol., 96, 633-655, 2011.
Singer, G. A., Fasching, C., Wilhelm, L., Niggemann, J., Steier, P., Dittmar, T., and Battin, T. J.: Biogeochemically diverse organic matter in Alpine glaciers and its downstream fate, Nat. Geosci., 5, 710-714, 2012.

Skjemstad, J. O., Clarke, P., Taylor, J. A., Oades, J. M., and McClure, S. G.: The chemistry and nature of protected carbon in soil, Aust. J. Soil Res., 34, 251-271, 1996.

Sobczak, W. V. and Findlay, S.: Variation in bioavailability of dissolved organic carbon among stream hyporheic flowpaths, Ecology, 83, 3194-3209, 2002.

Specht, C. H., Kumke, M. U., and Frimmel, F. H.: Characterization of NOM adsorption to clay minerals by size exclusion chromatography, Water Res., 34, 4063-4069, 2000.

Steinberg, C. E. W.: Ecology of humic substances in freshwater. Determinants from geochemistry to ecological niches, Springer, Berlin, Heidelberg, 2003.

Stuiver, M. and Polach, H. A.: Discussions of reporting ${ }^{14} \mathrm{C}$ data, Radiocarbon, 19, 355-363, 1977.

Tipping, E., Chamberlain, P. M., Fröberg, M., Hanson, P. J., and Jardine, P. M.: Simulation of carbon cycling, including dissolved organic carbon transport, in forest soil locally enriched with ${ }^{14} \mathrm{C}$, Biogeochemistry, 108, 91-107, 2012.

Tranvik, L. J.: Microbial transformation of labile dissolved organic matter into humic-like matter in seawater, FEMS Microbiol. Ecol., 12, 177-183, 1993.

Tranvik, L. J., Downing, J. A., Cotner, J. B., Loiselle, S. A., Striegl, R. G., Ballatore, T. J., Dillon, P., Finlay, K., Fortino, K., Knoll, L. B., Kortelainen, P. L., Kutser, T., Larsen, S., Laurion, I., Leech, D. M., McCallister, S. L., McKnight, D. M., Melack, J. M., Overholt, E., Porter, J. A., Prairie, Y., Renwick, W. H., Roland, F., Sherman, B. S., Schindler, D. W., Sobek, S., Tremblay, A., Vanni, M. J., Verschoor, A. M., von Wachenfeldt, E., and Weyhenmeyer, G. A.: Lakes and reservoirs as regulators of carbon cycling and climate, Limnol. Oceanogr., 54, 2298-2314, 2009.

Trumbore, S.: Age of soil organic matter and soil respiration: Radiocarbon constraints on belowground C dynamics, Ecol. Appl., 10, 399-411, 2000.

von Wachenfeld, E. and Tranvik, L. J.: Sedimentation in boreal lakes - The role of flocculation of allochthonous dissolved organic matter in the water column, Ecosystems, 11, 803-814, 2008.

Weishaar, J. L., Aiken, G. R., Bergamaschi, B. A., Fram, M. S., Fujii, R., and Mopper, K.: Evaluation of specific ultraviolet absorbance as an indicator of the chemical composition and reactivity of dissolved organic carbon, Environ. Sci. Technol., 37, 47024708, 2003.

Wetzel, R. G.: Gradient dominated ecosystems: Sources and regulatory functions of dissolved organic-matter in freshwater ecosystems, Hydrobiologia, 229, 181-198, 1992.

Wiegner, T. N. and Seitzinger, S. P.: Photochemical and microbial degradation of external dissolved organic matter inputs to rivers, Aquat. Microb. Ecol., 24, 27-40, 2001.

Wiegner, T. N., Seitzinger, S. P., Glibert, P. M., and Bronk, D. A.: Bioavailability of dissolved organic nitrogen and carbon from nine rivers in the eastern United States, Aquat. Microb. Ecol., 43, 277-287, 2006.

Wilson, M. A., Pugmire, R. J., and Grant, D. M.: Nuclear magnetic resonance spectroscopy of soils and related materials. Relaxation of ${ }^{13} \mathrm{C}$ nuclei in cross polarization nuclear magnetic resonance 
experiments, Org. Geochem., 5, 121-129, 1983.

Zak, D. R., Holmes, W. E., White, D. C., Peacock, A. D., and Tilman, D.: Plant diversity, soil microbial communities, and ecosystem function: Are there any links?, Ecology, 84, 20422050, 2003.
Ziegler, S. E. and Brisco, S. L.: Relationships between the isotopic composition of dissolved organic carbon and its bioavailability in contrasting Ozark streams, Hydrobiologia, 513, 153-169, 2004. 